\title{
THEORETICAL-LEGAL AND APPLIED ASPECTS OF THE NOTARIAL PROCEDURE CONCERNING THE CERTIFICATION OF WILLS
}

\section{Dolynska Mariia ${ }^{1}$}

DOI: http://dx.doi.org/10.30525/978-9934-571-29-9_4

Abstract. The article deals with the comprehensive analysis of implementing the notarial procedure concerning the certification of wills in Ukraine. Special attention is paid to the definition of the concept of wills. The author carried out the classification of wills according to the procedure of certification and the subjects entitled to certify the will. The purpose of the research is a comprehensive scientific-theoretical and practical analysis of the features of the legal regulation of the notarial procedure concerning the certification of wills. The tasks of the research are to determine the concept and types of wills, to carry out the characteristic of legal principles of certification of wills, to investigate the features of certification of wills. The subject of research is the theoretical achievements and modern practical tendency of the interpretation of the legal regulation of the notarial procedure concerning the certification of wills. The author applied general scientific and special methods of investigation, in particular: system, structural-functional and comparative methods. The issues of the restriction of the right to certify the wills are scrutinized. Analyzing the question of keeping the secrecy of notarial acts, the author proves that the fact of the violation of the secrecy of the will does not entail declaring the will invalid. The author emphasizes the fact that during certifying the wills, bodies of notariate and quasi-notariate should strictly adhere to the norms of the current legislation. The procedure of the certification of wills, including the wills that equal to notarial, is investigated in detail. In the current legislation the author proposes to establish the procedure for the substitution of the public individuals and official persons authorized to certify wills that equal to notarial. A will is a unilateral transaction, which is executed in writing with indication of the place and time of its construction, the information about the testator: the surname and name, patronymic name

${ }^{1}$ Doctor of Law, Associate Professor,

Head of the Department of Economic and Legal Disciplines,

Lviv State University of Internal Affairs, Ukraine 
(if there is); the registration number of the discount card of the taxpayer in accordance with the State register of natural persons - taxpayers or the reason of its absence; the place of residence or location; the date and place (if it is unknown-the name of the country) of birth, personally signed by the testator and certified by a notary or specially authorized officials.

\section{Introduction}

In Ukraine the persons specified in the will - that is the persons appointed in accordance with the will of the testator, have the priority right to succession. In default of the will, declaring it null and void, non-acceptance of inheritance, or refusal to accept by the testamentary heir (testamentary succession), the heirs have the right to legal succession (according to law).

Authorized bodies of notariate and quasi-notariate have the right to make and certify wills. The specified bodies of notariate must promote the exercise of rights of natural persons and legal entities, the protection of legitimate interests, and explain their rights and obligations. Problems of legal regulation of certifying the wills are one of the subjects of discussion, especially today, when the fundamental changes, due to the undeclared war and the actual occupation of the East of Ukraine, take place in the society. It is necessary to solve a number of problems standing before the public individuals and official persons authorized to certify wills that equal to notarial in the process of their testamentation. It is a question of urgent importance, because it will allow analyzing the normative and legal acts and their gaps concerning the notarial procedure of the certification of wills. Conclusions of the research will contribute to improving the notarial procedure of the certification of wills.

The purpose of the research is a comprehensive scientific-theoretical and practical analysis of the features of the legal regulation of the notarial procedure concerning the certification of wills.

The tasks of the research are to determine the concept and types of wills, to carry out the characteristic of legal principles of certification of wills, to investigate the features of certification of wills.

The object of the research is the legal regulation of the notarial procedure concerning the certification of wills.

The subject of research is the theoretical achievements and modern practical tendency of the interpretation of the legal regulation of the notarial procedure concerning the certification of wills. 
The question of the formation of the Ukrainian notariate was the subject of study of many scientists. In particular, the issue of the proceedings in the notarial procedure, including the issue of the certification of wills, was investigated by such scientists as: V. Barankova, N. Vasylyna, M. Diakovych, Yu. Zaika, V. Komarov, M. Matsehora, A. Nahorna, O. Nelin, S. Fursa, Ye. Fursa, Ye. Kharytonov, O. Kharytonova and others. However, these scientists did not pay enough attention to the notarial procedure concerning the certification of wills.

The author applied general scientific and special methods of investigation, in particular: system, structural-functional and comparative methods.

\section{Wills: concept, types and legal regulation of testamentation and certification}

The concept of a will as a personal arrangement made by a natural person in case of his/her death is given in Article 1233 of the Civil Code of Ukraine.

Thus, a will is a personal arrangement made by a natural person in case of his/her death, which is executed in writing with indication of the place and time of its construction and is certified by a notary or specially authorized officials. Natural persons in full civil capacity have the right to make a will, and making a will through a representative is not permitted. That is, the testator implements the right to dispose of property in case of death.

The list of subjects who have the power to certify a will is established in part three of Article 1247 of the Civil Code. In particular, a will is certified by a notary or other officials specified in Articles 1251-1252 of this Code.

Having analyzed the norms of Articles 1251-1252 of the Civil Code of Ukraine, Articles 1, 37, 38, 40 of the Law of Ukraine "On Notariate", we came to the conclusion that Article 1247 of the Civil Code does not include to the circle of persons who have the right to certify wills - officials of consular institutions of Ukraine, and in cases stipulated by the current legislation, diplomatic missions.

Bodies of notariate and quasi-notariate have the right to make and certify wills. Bodies of notariate include public and private notaries, and bodies of quasi-notariate include officials of local governments, other officials authorized to carry out certain types of notarial acts in accordance with the current legislation [1, p. 797]. 


\section{Theoretical-legal and applied aspects of the notarial procedure concerning...}

The peculiarity of the will lies in the fact that it contains the wish of the person during his/her lifetime, but the direct implementation of this wish is possible under an indispensable condition - the death of this person. This circumstance causes special requirements to the form and content of the will, because after the death of the testator, nobody has the ability to specify or clarify his/her intentions [2, p. 73].

As O. Kalinichenko affirms, "form" and "kind" of the will are not the same categories. We consider the form of the will as a way of expression of will, which is the procedure of certification of a specified transaction by the authorized public individuals, official persons. The specified procedure is determined by the subject of certification of the will and certain order of committing such actions. A kind of the will describes the content of this transaction (a will with condition, a will with substitution of heir, a will with institution of executor, etc.) or subject composition (a personal will; a marital will), and it does not concern the procedure of certification. We support the opinion of the scientist that we can classify wills according to two criteria: depending on the subject of certification and the procedure of certification. Depending on the subject of certification, wills can be classified into the following groups: notarial and non-notarial that equal to notarial form [3, p. 112]. At the same time, it is advisable to consider "nonnotarial wills" as quasi-notarial because this concept is much wider than wills that equal to notarial.

Depending on the procedure of certification, wills are divided into three groups: an ordinary will; a will in the presence of witnesses; a secret will.

An ordinary will is certificated according to the rules of Article 1247 of the Civil Code of Ukraine. It is executed in writing with indication of the place and time of its construction. The testator has the right to include either the entire inheritance, or a part thereof in the will and to institute one or several natural persons or other participants of civil relations, the territorial community or the state as his/her heirs.

A will in the presence of witnesses is certificated in accordance with Article 1253 of the Civil Code of Ukraine.

The legislator establishes two types of certification of wills in the presence of witnesses. The first type - it takes place at the request of the testator, and the second - at the obligatory presence of witnesses. A will in the presence of witnesses is regulated by Articles 1248, 1252 of the Civil Code of Ukraine. 
A secret will is certificated only by public and private notaries. In accordance with Article 1249 of the Civil Code of Ukraine, a secret will is the will certified by the notary without reading its contents. The person who constructed the secret will should submit it in a closed envelope to the notary. The envelope must have the testator's signature. The notary makes a notarial record, attaches a seal on the envelope, and puts it in another envelope and seals in the testator's presence.

We agree with the opinion of $\mathrm{O}$. Kalinichenko that the main goal of the institution of the secret will is to protect the secrecy of the will [3, p. 112].

Ukrainian scientists S. Fursa and Ye. Fursa rightly draw the analogy between certification of a secret will and such a notarial act as acceptance of the document for storage, according to which the document can be taken by the notary without getting acquainted with its contents [4, p. 66].

In article 1243 of the Civil Code the legislator provides that a married couple may make a joint will with regard to the property jointly owned thereby.

We support the position of N. Shama, as a joint will is a variety of a will, and hence the unilateral transaction in which one side is represented by several persons, namely a married couple, then the possibility of making it is caused by the presence of two conditions simultaneously:

1) the marriage status of persons who wish to make a joint will; and

2) the presence of full legal capacity required for making a will in each of the spouses [5, p. 179].

In our opinion, the specificity of this will is that:

- to devise only the property jointly owned,

- the person that determined by agreement between the spouses should get the hereditary property,

- the spouse who survived continues to live in a normal property environment [6, p. 13].

It is worth to emphasize, that in case of death of one of the spouses, a share in joint ownership belonging to a deceased spouse passes to the survivor. The legislator established that the spouse who survived does not have the right to alienate the property that was the joint property of the spouses and the object of the joint will.

Heirs of the marital will are persons instituted in the will; however, they can take possession of the property only after the death of both spouses. 
In accordance with part three of Article 1243 of the Civil Code, in the lifetime of both spouses, either of them has the right to refuse from the joint will. The refusal from the joint will should be notarized. However, the application cannot cancel a joint marital will. In our opinion, in this case it is necessary to use a mutual cancellation of previously joint will made by both members of the couple. In practice, a marital will is not wide spread. In case of death of one of the spouses, the latter (who remained alive and is not a person of advanced age), mainly, changes his/her mind of the future heir. Therefore, most of notaries offer each of the spouses to make a separate will for a part of the property earned during the time of the registered marriage.

We agree with N. Vasylyna that after dissolution of marriage the former spouses do not lose the opportunity to leave the right to preserve their will for the property jointly owned [7, p. 111].

Certification of wills by notaries and authorized public individuals and official persons takes place in accordance with the current legislation, including the civil and notarial legislation.

In our opinion, the Ukrainian modern legislation on notariate is a set of normative and legal acts that are accepted by the authorized public bodies, in which there are rules regulating the organization and competence of notarial bodies of the state, procedural order of making notarial acts, as well as committing other actions, different from notarial, with the aim of providing them with a legal reliability [8, p. 363, 376].

The acts of other branches of law governing the separate questions of organization of notariate and exercise of notarial activities include, for example, the Civil Code of Ukraine, the Family Code of Ukraine, the Land Code of Ukraine, the Tax Code of Ukraine and others [8, p. 315].

Having made the analysis of notarial activities of independent Ukraine, we came to a conclusion "about the need for separation of its three parts, namely:

the legislation regulating the general principles for the creation and activities of notariate and quasi-notariate;

the legislation regulating the procedure of notarial acts;

the legislation regulating the commitment of other actions, different from notarial, with the aim of providing them with a legal reliability [8, p. 367].

While certificating wills notaries, public individuals, official persons, consular officials must comply with the Constitution of Ukraine, the Civil, Family, Land Code of Ukraine, the Law of Ukraine "On Notariate", the 
Consular Statute of Ukraine, the Procedure of certifying wills and powers of attorney that are equal to notarial, as well as other normative and legal acts.

It should be emphasized that the legislation has determined certain public individuals, official persons who have the right to do it in the process of certifying wills that are equal to notarial.

Analyzing the norms of Article 1252 of the Civil Code of Ukraine, as well as Article 40 of the Law of Ukraine "On Notariate", we define subjects of certifying wills and powers of attorney that are equal to notarial.

In accordance with Articles 1251-1252 of the Civil Code of Ukraine, Articles 1, 37, 38, 40 of the Law of Ukraine "On Notariate" the subjects who have the right to certify wills are:

- public and private notaries (Article 1248 of the Civil Code of Ukraine "Certification of Wills by Notary", Article 36 of the Law of Ukraine "On Notariate");

- authorized officials of the relevant local government (Article 1251 of the Civil Code of Ukraine "Certification of Wills by Local Government Officials", Article 37 of the Law of Ukraine "On Notariate");

- other public individuals and official persons (Article 1252 of the Civil Code of Ukraine "Certification of Wills by Other Officials", Article 40 of the Law of Ukraine "On Notariate"), namely:

1) a chief medical officer, or a deputy thereof, or a doctor on duty of the hospital, or other in-patient health care institution, or the director or chief medical officer of the old people's home or invalids' asylum;

2) a person on board a sea or river vessel under the flag of Ukraine;

3) a person participating in a search party or expedition;

4) the commander (head) of the unit, detachment, institution, military training institution;

5) a prison governor;

6) the head of the trial center.

- officials of the consular institutions of Ukraine, and in cases stipulated by law, diplomatic representatives (Article 38 of the Law of Ukraine "On Notariate").

Only public notaries who work at state notary's offices have the right to certify wills. State notaries of public notary archives are deprived of such rights. They issue only duplicates of wills that are in their possession.

In accordance with Article 9 of the Law of Ukraine "On Notariate" "Restrictions of notarial acts", a notary and an official of local self- 
government, who commit notarial acts, have no right to perform notarial acts in their name and on behalf of their name, in the name of and on behalf of their husband or their wife, his (her) and their relatives (parents, children, grandchildren, grandfather, grandmother, brothers, sisters), and also in the name of and on behalf of the employees of the notary's office, workers who are in labor relations with a notary public, or staff members of the executive committee. Officials of local government are also not entitled to perform notarial acts in the name of and on behalf of this executive committee. In these cases, notarial acts are committed at any other public notary's office, at the private notary or at the executive committee of another village, township, and city Council of people's deputies.

You should pay attention to the fact that in the norms the legislator has "forgotten" about notarial acts committed by authorized consular officials. Restrictions of notarial acts for specified persons are regulated by Article 49 of the Consular Statute of Ukraine, approved by the Decree of the President of Ukraine dated April 2, 1994, no. 127/94. The consul cannot perform notarial acts, including wills, in his name and on behalf of his name, in the name and on behalf of her (his) wife (husband), her (his) and their lineal relatives. That is, the consul can certify a will on behalf of the employees of the consulate, which is not valid as for us.

Public individuals, official persons listed in Article 40 of the Law of Ukraine "On Notariate" that certify the wills equal to notarial, are not entitled to certify wills in their name and on behalf of their name, as well as in the name of and on behalf of his wife or her husband. Specified public individuals, official persons have also no right to perform wills on behalf of their sons and daughters, mother, father, grandchildren, grandfather, grandmother, including their brothers or sisters.

The law states that in this case wills and power of attorney are not valid.

The legislator refers to the duties of a notary (in accordance with Article 5 of the Law of Ukraine "On Notariate") to keep confidential information obtained by him/her in connection with making notarial acts. Swearing the oath a person who first is engaged in notarial activities takes his oath to keep professional secrets.

The question of keeping the notary's secrecy has its historical experience. For example, the question of the secrecy of notarial acts was settled by Austrian Notarial Regulations dated July 25, 1871. In accordance with paragraph 37 of the Regulations, the duties of a notary public included not 
only his keeping the secrecy of notarial acts before the parties, but also supervising over the observance of secrecy by his assistants. In particular, the notary guaranteed that all information of the notarial act that took place in his presence, actually took place in his presence in that way; the notary was responsible for all inexactitudes, even if they had been committed due to an error. The indemnification did not abolish a penalty of dignity for nonperforming notary's duties.

At the time of independence of Ukraine, the question of keeping the secrecy of notarial acts has been attracting the attention of legislators. Article 8 of the Law of Ukraine "On Notariate" dated September 2, 1993 in the original edition was called "The observance of secrecy of committed notarial acts" and it did not contain the concept of notary's secrecy. The article has undergone numerous changes, additions and redactions of individual parts and as a whole. Only the Law of Ukraine "On amendments to the Law of Ukraine "On Notariate" dated October 1, 2008, no. 614-VI issued the new wording of Article 8 of the Law, which changed the title of the article and at the legislative level the definition of notarial secrecy was given. Notarial secrecy is the totality of the information obtained during committing the notarial act or addressing the interested party to a notary, including the information about property, personal property and nonproperty rights and obligations, etc.

Notarial secrecy needs to be treated with the two sides. On the one hand, it is the secrecy of a person addressing to making the notarial act (the motive and the fact of addressing to the notary; providing with documents; achieving the result after addressing to the notary; information about the private life of a person, etc.), on the other hand - it is the secrecy of the notary as a specialist (information about advice, consultations, etc.). These two characteristics of the concept of the secrecy of notarial acts are important. We support the opinion of S. Fursa and Ya. Panteliienko that both concepts of the secrecy of notarial acts must be legislatively fixed $[9$, p. 87].

Notarial secrecy must be kept by:

- notaries who work at state notary's offices, state notarial archives or are engaged in private practice as a notary;

- officials of the local authorities who are authorized to perform notarial acts;

- officials of consular institutions who commit notarial acts; 
- officials who in accordance with Articles 40 and 40-1 of the Law of Ukraine "On Notariate" commit notarial acts;

- persons who got to know about committing notarial acts in connection with performance of their official duties or work; persons involved in notarial acts as witnesses and other persons who got to know information that was the subject of notarial secrecy. Such persons also include: assistant, consultant, secretary, clerk of a notary, even if their activity is limited to providing legal assistance or familiarization with documents and the notarial act was not committed.

We agree with M. Diakovych that "actually the secrecy of notarial activities, including notarial acts, must ensure inviolability of private life of citizens who apply to a notary. Sometimes a notary is compared with the priest, to whom a person can confess and trust him with all his/her cherished sides of life, which should not be spread, because it is a seal of confession. Similarly, the notary is responsible for divulging of secrets of notarial acts. The person who trusts the notary with his/her secrets, respectively, should have certainty that all information discussed with the notary will never become the subject of public discussion" [10, p. 73].

Persons that are guilty of violating the notarial secrecy will bear responsibility in order established by law.

There is the reason in views of S. Leskiv and A. Chubenko that the secrecy of the will consists in the following: before opening of inheritance persons signing the will for the testator are deprived of the right to divulge secret information about 1 ) the fact of making the will; 2) the contents of the will; 3) the cancellation or modification of the will [11, p. 158].

In accordance with the judicial practice, during certification of the will the fact of violation of the secrecy of the will does not entail declaring it invalid, but only in the presence of other violations of law. This is also confirmed by the explanations of the Plenum of the Supreme Court indicated in paragraph 8 of resolution no. 2 (v0002700-92) dated January 31,1992 "On judicial practice in cases involving complaints about notarial acts or refusal of their committing" where a notarial act cannot be cancelled only for reasons of underexposed secrets of its committing because the legislation on notariate does not provide such consequences.

We agree with D. Zhuravlov, O. Korotiuk and K. Chyzhmar that the subject of the notarial secret is protected by law as information with restricted access, namely - secret information. The secret information 
includes information not only about the person who applied for taking notarial acts, but also information about the provided advice, etc. [12, p. 52].

Notaries', public individuals, official persons who certificated wills, can give information or papers about their certification to individuals who concluded those documents or to others by their power of attorney. If persons, on behalf of whom the documents had been concluded, died, then the information or papers are issued to their heirs. However, under the law, public individuals, official persons who certificated wills, can give papers about their certification within ten working days upon reasonable written request to the Court, the Prosecutor's Office, the bodies of the pre-trial investigation, operative units in connection with criminal proceedings, civil, economic, administrative cases, administrative offences that are under the proceedings of specified bodies, with the obligatory indication of the numbers (criminal proceedings) and affixing the stamp seal of the authorized body.

Although the principle of freedom of the will gives a wide scope of legal authorities for post-mortuary disposition to the testator, but at the same time it limits his/her right to deprive the rights of inheritance of the compulsory heirs [13, p. 10].

The testator has no right to deprive the rights to inheritance of those heirs who are legally entitled to a hereditary portion of the right to succession. According to Yu. Zaika, such persons should be called forced heirs [14, p. 136].

It should be noted that the right to hereditary portion of inheritance was existed in the Roman law, which was a quarter of a legal portion, i. e., the portion that the heir would have received in case of legal succession (compulsory portion).

According to Ye. Fursa, the right to hereditary portion - it is a redistribution of inheritance by the state taking into account the interests of the most vulnerable sections of citizens in case of no stating them in the will or violation of their rights within the contents of the will. This position is understandable, and this right of the state is no doubt today, because some people need extra protection of their interests. The author also hopes that in future our country will provide such persons with aid at its expense [15, p. 75].

Only persons determined in part 1 of Article 1241 of the Civil Code of Ukraine have the right to hereditary portion of inheritance. Such persons include: 
1) the testator's juvenile children, grown-up incapable children (including the adopted),

2) incapable widow (widower),

3) irrespective of the will, incapable parents inherit half of the shares that would belong to each of them in case of legal succession (compulsory portion).

The specified list is not subject to the extended interpretation, i.e. it is exhaustive.

In this case the right to hereditary portion of inheritance does not depend on the consent of the other heirs, the volition of the testator; and it is not connected with joint residence of the testator and persons who have the right to the compulsory portion. The right to hereditary portion of inheritance has personal nature and may not move in the order of hereditary transmission [16, p. 240].

Thus, a will is a unilateral transaction made by a natural person in case of his/her death, which is executed in writing with indication of the place and time of its construction, personally signed by the testator and certified by a notary or specially authorized officials.

\section{Features of the proceedings in the notarial procedure concerning the certification of wills}

Notarization of wills takes a special place among the notarial acts, especially in state notary's offices and in the bodies of local self-government.

The advantages of the notarial form of the transaction are that it provides a greater degree of legitimacy and credibility of its contents, clarity and certainty regarding the fact of committing the agreement. To make sure that the transaction complies with the law, the notary defines the essence of the respective relations, explains their legal qualifications, checks the capability of the natural person, as well as its actual will. In addition, the notary has appropriate education and work experience, which greatly reduces the possibility of declaring the will null and void in accordance with the court decision after opening of the inheritance [3, p. 110].

Before certification of the will, the notary, the authorized public individuals, official persons are obliged to explain the testator's rights:

- irrespective of any family relations, the testator may institute one or several natural persons or other participants of civil relations as his/her heirs; 
- in case of making the will in favor of several persons, the testator institutes the hereditary portion of his/her property to each of the heirs;

- the testator may leave all his/her property or a share of it, in particular, the usual household and private items, as well as leave the property which would become his/her property in future and which would be at the testator's disposal at the day of his/her death;

- without specifying the reasons, the testator may divest any of the legal heirs of the right to succession;

- the testator has the right to make testamentary renunciation in the will, or legate;

- the testator has the right to modify or cancel the will at any time and to make a new will. A later will cancels the previous will fully or in the part where it contradicts the latter;

- the testator has the right to appoint a testamentary executor (only by his/her consent), who acts as the guarantor of the implementation of the testator's will.

According to the Regulations on Hereditary Register, the notary, an official of local self-government, other public individuals, official persons must specify the date and place of birth of the testator in the text of the will.

Persons that cannot make a will are:

- adult persons recognized incapable in accordance with the court decision (for example, persons who are not capable to realize the significance of their actions and (or) control them due to chronic, stable psychological disorder);

- adult persons in limited civil capacity, in accordance with the court decision as a result of the abuse of alcohol, narcotic, toxic substances, etc. [6, p. 10].

First of all, the testator must be legally capable at the moment of making the will. The further loss of capacity by the testator after making the will is not the basis of declaring the will null and void. However, in the case of making the will by the incapable person, it (the will) will be always null and void.

Irrespective of any family relations, the testator may institute one or several natural persons or other participants of civil relations as his/her heirs. Without specifying the reasons, the testator may divest any of the legal heirs of the right to succession.

We agree with the opinion of M. Matsehora that while giving the right to certify the wills to public individuals, official persons - the legislator 


\section{Theoretical-legal and applied aspects of the notarial procedure concerning...}

follows the humane principle: to give a chance to express a will of the person [17, p. 148].

S. Sibilova states that the essence of the freedom of the will consists in the right of the testator to act freely, but it is necessary to point out two circumstances. The essence of the first circumstance is the testator, making the will, determines the fate of his/her property in case of death, i.e. carries out the powers that belong to him/her as the owner of the property. In accordance with part 1 of Article 319 of the Civil Code of Ukraine, the owner possesses, uses and disposes of his/her property at his/her own discretion. The essence of the second circumstance is the hereditary relationship is one of the kinds of civil relations. Not only the participants of hereditary relationships have the right to act freely, but the participants of all other civil relations have it too and it is based on the principle of autonomy of the will of each of them. Since unilateral transactions may be regulated not only by the general norms, but also the special norms that apply to certain unilateral transactions, Article 3 of the Civil Code of Ukraine should be provided with the warning that freedom of the unilateral transaction exists only in cases if other is not established by law governing a specific kind of the unilateral transaction [18, p. 135-140].

We consider it is necessary to pay a special attention to a notarial procedure of certification of wills in the presence of witnesses.

Only persons in full civil capacity may be witnesses. The following persons cannot be witnesses: notaries or other officials certifying the will; testamentary heirs; family members and close relatives of testamentary heirs; and persons incapable of reading and signing the will due to illness or physical disability.

O. Kukhariev made a properly confirmed conclusion that witnesses involved in the procedure of certification of wills should testify:

a) at the moment of testamentation and certification of the will, the testator understood the significance of his/her actions and could control them (this fact can be established only by witnesses visually);

b) the testator expressed his/her true will, and mental or physical influence was not applied to him/her;

c) the testator personally signed the will, or by the testator's request the will was signed by another person in his/her presence [19, p. 109].

Wills in the presence of witnesses should contain the witnesses' personal data: surname, name and patronymic name of the witness, the date of his/ 
her birth, the place of residence, and requisites of the passport or other document based on which the identity of the witness was established.

The witnesses in whose presence the will is certified should read it aloud and put their signatures thereon.

The witness is responsible for harm caused by him/her because of divulging of information, which became known in connection with his/her participation in committing the statutory notarial act.

We share the thought of S. Fursa about expediency of the creation of the State Register of Persons, limited in capacity and incapable, herewith notaries and other public individuals, official persons who use the specified information in their activities should have free access to the specified register [20, p. 320].

A similar mechanism is to greatly simplify the procedure of checking the capacity of natural persons, and therefore the certification of wills, reduce the number of refusal to commit the notarial acts [21, p. 64].

Natural persons in full civil capacity have the right to make a will. The will is constructed by one natural person (excepting the marital will). Making the will through a representative is not permitted. The will is executed in writing with indication of the place and time of its construction, the date and place of birth of the testator. The will must be personally signed by the testator.

The testator may write the will manually or using the common technical devices.

By the testator's request, public individuals, official persons may construct the will at the testator's dictation manually or using the common technical devices. In this case, the will shall be read aloud and signed by the testator.

If a testator cannot read or sign the will because of physical incapability, the will is certified in presence of two witnesses and another natural person can sign the will.

To certify the will, the testator is not required to submit documents confirming his/her right to hereditary property. Property may be testate only for ownership. The testator may impose on a heir inheriting a house, apartment or other movable or immovable property an obligation to convey the right to use the said pecuniary right or property (some part of it) to a third person. The right to use a house, apartment or other movable or immovable property shall remain valid in case of consequent change of the owner thereof. The text of the will is constructed so that the disposal 


\section{Theoretical-legal and applied aspects of the notarial procedure concerning...}

of the testator would not excite misunderstanding or doubts at the time of executing the inheritance.

The notary, authorized public individuals, official persons have the right to testify the will with condition. For the creation of the right to succession, the testator may envisage a certain condition for the person specified in the will either related or not related to this person's behavior (existence of other heirs, residence at a certain place, birth of a child, education, etc.) The condition established in the will should exist at the moment of opening of the inheritance. A condition established in the will shall be void if it contradicts law or moral principles of the society.

If there is a situation when the person-testator envisages the condition of observing the moral principles of the society, therefore it is necessary to apply to the provisions of the Law of Ukraine "On Protection of Public Morality", in which public morality is revealed as a set of rules of behavior and ethical standards based on the human ideas of kindness, honor, dignity, as well as on the cultural and spiritual values. We agree with N. Fomichova that the will with condition has already existed for a long time, but there is the problem of its legislative regulation now [22, p. 259].

The testator may oblige the heir to take certain actions of non-pecuniary nature, particularly with regard to disposal of personal documents and to take certain actions aimed at the achievement of socially beneficial goals etc.

During certification of the will the notary, authorized public individuals, official persons should explain the contents of Article 1241 of the Civil Code of Ukraine concerning the right to hereditary portion to the testator and the contents of Article 1307 of the Civil Code of Ukraine concerning the void will made by the alienator with regard to the property specified in the succession agreement.

In case of certification of the will on deposit, which is stored in the Bank (financial institution), the text of the will specifies the number of the account, the full name and location of the Bank (financial institution), which kept the deposit.

The will is constructed and certified in duplicate. It is not allowed the presence of the natural person in favor of whom the property is instituted; the natural person cannot be present during the signing of the will, as well as sign it instead of the testator.

The notary, authorized public individuals, official persons certifying the will cannot sign the will instead of the testator. 
The captain of the sea or river vessel under the flag of Ukraine should transmit one copy of the will certified by him to the chief of the Ukrainian port or the consul of Ukraine in a foreign port for transferring it to the state notarial archive at the permanent place of residence of the testator.

If the testator had no permanent place of residence in Ukraine or the place of his/her residence is unknown, the will is transmitted to the Kiev State Notarial Archive.

It is worth noting, the information that certified wills are liable entering in the Succession register was introduced by the order of the Ministry of Justice of Ukraine dated October 17, 2000, no. 51/5 "On Succession Register". According to the fifth provision of the order, all wills, constructed and certified, modified or cancelled per the procedure established by the law, started succession cases and issued certificates of inheritance from December 01, 2000 are subject to mandatory registration in the Succession register [23, p. 56].

As of 2018, wills are subject to mandatory state registration in the Succession register per the procedure established by Regulations on Succession register approved by the order of Ministry of Justice of Ukraine dated July 07, 2011 no.1810/5, registered in the Ministry of Justice of Ukraine on July 11, 2011no. 831/19569.

In particular, in accordance with paragraph 2.1.1. of the Regulations, the registrar enters the following information about the testator (testators, in case of certification of a joint will of a married couple) in the Succession register: surnames and names, patronymic names (if there are) of the testator (testators); the registration number of the discount card of the taxpayer in accordance with the State register of natural persons taxpayers or the reason of its absence; the place of residence or location; the date and place (if it is unknown-the name of the country) of birth. Therefore, the listed information should be necessarily mentioned in the text of the will.

Entering the information about wills in the Succession register, which are certified by the authorized public individuals, official persons, indicated in Article 1252 of the Civil Code of Ukraine and part 1 of Article 40 of the Law of Ukraine "On Notariate", is carried out by state notarial archives in case of accepting a copy of the will in storage.

It is appropriate to note that the secret wills are not widely spread in Ukraine. In particular, there is a problem with the announcement of the 
secret will. Notaries-practical workers offer to solve the problem in the following way. While bearing the testator's signature on the secret wills the notary offers to make a list of the persons whom the notary would invite during the announcement of the will.

Information about the presence of the constructed will, with the exception of the testator, is issued only after the death of the testator according to a submission of a certificate (notarized copy) of his/her death.

Analyzing the question of the certification of wills by a captain of the ship A. Nahorna draws attention to the fact that the captain has no legal education and has a little practice of certifying the wills, it can lead to issues unregulated by the legislator [24, p. 180].

Examining the wills certified by heads of a search party or expedition A. Nahorna offers "a simplified procedure of the certification of wills during expeditions" [25, p. 180].

When developing the idea of the certification of wills by bodies of quasinotariate it is necessary to emphasize that notarial acts in local governments are committed only by persons who can perform notarial acts based on the decision of the Executive Committee. Deciding the question of the authority for committing notarial acts and acts that equal to notarial, the body of local government takes into account the presence of legal education, practical skills for notarial acts, etc. As a rule, in the decisions you should provide for another person who will perform notarial acts in the absence of a primary worker (vacation, illness, business trip, etc.).

This practice should be applied to public individuals, official persons listed in Articles 40, 40-1 of the Law of Ukraine "On Notariate". Thus, it is necessary to make the appropriate changes to the Law of Ukraine "On Notariate" and the Civil Code of Ukraine.

We agree with the opinion of most researchers, including M. Matsehora, that the lack of legal qualification of public individuals, official persons entitled to certify causes insufficient explanation of the testator's rights and obligations, even breaking the form of the will [17, p. 148].

As public individuals, official persons certifying the wills that equal to notarial do not possess the necessary knowledge of current legislation regarding the certification of wills, in particular in the field of civil, family, land law, it causes insufficient explanation of the testator's rights and obligations, i.e. restricts the right of the latter to objective declaration of intention during construction of wills or powers of attorney. 


\section{Dolynska Mariia}

S. Leskiv and A. Chubenko prove that at present there is no effective mechanism for the protection of the testator's rights from different violations and therefore there is an objective need for amending current legislative acts [11, p. 159].

The procedure of declaring the will null and void is established in Article 1257 of the Civil Code of Ukraine.

According to S. Sibilova, the will can be neither void nor feigned $[26$, p. 210]. The legislator proves that only the court may declare a will null and void if it establishes that the testator's will was not free or did not conform to his/her intention.

Consequences of invalidity of a separate arrangement in the will and the will in general are provided by norms fixed, respectively, in parts 3 and 4 of Article 1257 of the Civil Code of Ukraine. These norms are special. There is a textual discrepancy between the general rule fixed in Article 217 of the Civil Code of Ukraine concerning legal consequences of invalidity of separate parts of transaction and rules fixed in Article 1257 of the Civil Code of Ukraine concerning invalidity of a separate arrangement in the will. In accordance with the general norm, invalidity of a separate part of a transaction shall not entail invalidity of its other parts or of the transaction as a whole, where it might be assumed that the transaction could have also been concluded without inclusion of the invalid part therein. In accordance with the special norm, declaring null and void of a separate arrangement in the will shall not entail declaring its other parts null and void without any assumptions [27, p. 279].

In our opinion, one of the most important reasons of declaring the will null and void is certification of the will that equal to notarial by public individuals and official persons without the presence of two witnesses.

Declaring the will null and void or declaring it invalid in accordance with the court decision is one of the types of protection of hereditary rights and interests. There are a number of discursive and unsolved issues of financial and procedural nature that complicate the implementation of the hereditary rights and interests of heirs. The most common grounds for declaring the will null and void are the presence of a defect of will (desire), which is checked by conducting the death forensic psychiatric examination. The grounds for declaring the will invalid are not limited only by Article 1287 of the Civil Code of Ukraine, but other norms of the civil legislation concerning the invalidity of the transaction are also subject to the application. In order to provide hereditary rights and interests by the notary and to avoid errors 


\section{Theoretical-legal and applied aspects of the notarial procedure concerning...}

during construction of the will, which can lead to the possibility of recourse to the court for the purpose of declaring the will invalid, we agree with the authoritative opinion of Ukrainian scientists A. Chubenko and S. Leskiv to exclude Article 1245 of the Civil Code of Ukraine concerning the secret will [28, p. 167].

\section{Conclusions}

The following theoretical conclusions were formulated:

1. Legal regulation of the proceedings in the notarial procedure in Ukraine, in particular the certification of wills, is carried out by a large number of normative and legal acts.

2. Certification of wills that are equal to notarial is conducted by notaries, public individuals, official persons in accordance with the current legislation of Ukraine.

3. We suggest the following definition of the will. A will is a unilateral transaction, which is executed in writing with indication of the place and time of its construction, the information about the testator: the surname and name, patronymic name (if there is); the registration number of the discount card of the taxpayer in accordance with the State register of natural persons - taxpayers or the reason of its absence; the place of residence or location; the date and place (if it is unknown-the name of the country) of birth, personally signed by the testator and certified by a notary or specially authorized officials.

4. We suggest supplementing the third part of Article 1247 of the Civil Code with the following sentence: "Certification of wills abroad is carried out by the consular institutions of Ukraine, and in cases stipulated by the current legislation, by diplomatic missions of Ukraine".

5 . There is the same procedure of testamentation and certification of wills by notaries and officials of local self-government as well as by authorized public individuals and official persons. However, public individuals and official persons have the right to certify the wills that equal to notarial only with the participation of at least two witnesses.

6. The lack of legal education (not necessarily higher legal education) and practical experience in drafting legal documents of public individuals and official persons entitled to make wills that equal to notarial in practice leads to breaking the form of the will and declaring it invalid in accordance with the court decision. Therefore, we recommend public individuals and official 
persons to constantly work on improving their legal level, in particular in the field of civil, family, and land law. Authorized territorial bodies of the Ministry of Justice of Ukraine should provide public individuals and official persons with methodical recommendations on certification of wills that equal to notarial with appropriate samples of the documents.

7. In the current legislation we propose to establish the procedure for the substitution of the public individuals and official persons authorized to certify wills that equal to notarial.

The prospects for further research are the more detailed analysis of the notarial and judicial practice concerning the certification of wills.

\section{References:}

1. Dolynsjka M.S. (2015) Stanovlennja ta rozvytok pravovogho reghuljuvannja notarialjnoji dijaljnosti $v$ Ukrajini [Formation and development of legal regulation of notarial activity in Ukraine]. Ljviv: LjvDUYS. (in Ukrainian)

2. Zajika Ju.O. (2004) Forma zapovitu jak umova jogho dijsnosti [Form of will as a condition of its validity]. Visnyk Khmeljnycjkogho instytutu reghionaljnogho upravlnnja ta prava, no. 1-2, pp. 73-76.

3. Kalinichenko O. (2004) Formy zapovitu za Cyviljnym kodeksom Ukrajiny [Forms of the will according to the Civil Code of Ukraine]. Visnyk Kyjivsjkogho nacionaljnogho universytetu imeni Tarasa Shevchenka. Jurydychni nauky, vol. 88, pp. 110-112.

4. Fursa S. Ja., Fursa Je. I., Klymenko O. M. (2007) Spadkove pravo: Notariat. Advokatura. Sud: Nauk.-prakt. posib. [Hereditary right: Notary. Advocacy. Court: Sciences. Pract. manual]. Kyjiv: Vydavecj Fursa S. Ja. : KNT. (in Ukrainian)

5. Shama N. (2013) Pravo na spiljnyj zapovit [The right to a common will]. Proceedings of the Problemy derzhavotvorennja i zakhystu prav ljudyny $v$ Ukrajini (Ukrain, Ljviv, ljutyj 7-8, 2013) (eds. Bojko A.M., Semkiv V.O., Rabinovych P.M., Kossak V.M., Nor V.T., Pylypenko P.D., Ghuralj P.F., Tyshhyk B.J.), Ljviv: Jurydychnyj fakuljtet Ljvivsjkogho nacionaljnogho universytetu imeni Ivana Franka, pp. 179-181.

6. Dolynsjka M.S. (2007) Spadkuvannja v Ukrajini [Inheritance in Ukraine]. Dovidnyk notariusa. vol. 5, $96 \mathrm{pp}$.

7. Vasylyna N. V. (2014) Pravo na zapovit ta okremi pytannja jogho realizaciji [The right to testament and features of its realization]. Naukovyj visnyk Uzhghorodsjkogho nacionaljnogho universytetu, vol. 28, pp. 107-111.

8. Dolynsjka M.S. (2017) Stanovlennja ta rozvytok zakonodavstva pro notarialjnu dijaljnistj $v$ Ukrajini [Formation and development of the notarial activities legislation in Ukraine] (PhD Thesis), Ljviv: Ljvivsjkyj nacionaljnyj universytet imeni Ivana Franka.

9. Fursa S. Ja. (ed) (2012) Teorija notarialjnogho procesu: Naukovo-praktychnyj posibnyk [Theory of the notarial process: Scientific and practical manual]. Kyjiv: Alerta. (in Ukrainian) 


\section{Theoretical-legal and applied aspects of the notarial procedure concerning...}

10. Djakovych M.M. (2018) KHrestomatija notarialjnogho prava Ukrajiny: Navch.posibn. [Textbook of the Notary Law of Ukraine: Teach. manual]. Kyjiv: Istyna. (in Ukrainian)

11. Lesjkiv S. R. Chubenko t A. Gh. (2014) Svoboda zapovitu i tajemnycja zapovitu jak jurydychni gharantiji realizaciji prava na spadkuvannja za zapovitom [Freedom of the will and mystery of will as a legal guarantees of right to inheritange by will [Naukovyj visnyk Uzhghorodsjkogho nacionaljnogho universytetu]. Serija pravo, vol. 29, pp. 156-159.

12. Zhuravljov D. V., Korotjuk O.V., Chyzhmarj K. I. (2017) Pravova okhorona notarialjnoji tajemnyci: monoghrafija [Legal protection of notarial secrets]. Kyjiv: OVK. (in Ukrainian)

13. Zajika Ju.O., Rjabokonj Je. O. (2009) Spadkove pravo: Navch.posibn. [Hereditary right: teach. manual]. Kyjiv: Jurinkom Inter. (in Ukrainian)

14. Zajika Ju.O., Spivak V.M. (2000) Pravo vlasnosti. Spadkove pravo: Navchaljyj posibnyk [Ownership. Hereditary right: teach. manual]. Kyjiv: Naukova dumka. (in Ukrainian)

15. Fursa S. Ja., Fursa Je. I. (2002) Spadkove pravo: Teorija ta praktyka: Navchaljyj posibnyk [Inheritance right Theory and practice: a manual ]. Kyjiv: Atika. (in Ukrainian)

16. Dolynsjka M.S. (2012) Osoblyvosti vydachi notariusamy svidoctv pro pravo na spadshhynu za zapovitom [Features notaries issuing certificates of inheritance by will ]. Visnyk Ljvivsjkogho universytetu. Serija jurydychna, vol. 56, pp. 237-243.

17. Maceghora M. V. (2007) Forma zapovitu: stanovlennja, rozvytok, suchasni vymoghy [Form of the will: becoming, development and modern requirements]. Forum prava [Forum law] (electronic journal), no. 2, pp. 146-150. Available at: http://nbuv.gov.ua/UJRN/FP_index.htm_2007_2_24, (accessed 05 december 2017).

18.Sibiljova S. (2012) Svoboda zapovitu za chynnym cyviljnym zakonodavstvom Ukrajiny [Freedom of the will under current civil law of Ukraine ].Visnyk akademiji pravovykh nauk Ukrajiny, no. 2, pp. 131-140.

19. Kukharjev O. Je. (2011) Spadkove pravo Ukrajiny: Navch. - prakt. posib. [Hereditary Law of Ukraine: Teach. - practice manual]. Kyjiv: Alerta ; CUL. (in Ukrainian).

20. Fursa S. Ja. (2002) Notarialjnyj proces: Teoretychni osnovy [Notarial process: Theoretical basis]. Kyjiv: Istyna. (in Ukrainian)

21. Kalinichenko O. (2013) Shhodo posvidchennja zapovitiv nachaljnykom slidchogho izoljatora [As to the certificate of wills, the head of the investigatory detention center]. Bjuletenj Ministerstva justyciji Ukrajiny, no. 6, pp. 60-66.

22. Fomichova N. V. (2016) Skladannja zapovitu z umovoju ta dijsnistj vyznachenykh umov u mezhakh jikh vykonannja za zakonodavstvom Ukrajiny [Composing a will with a provision and actuality of particular provisions within the limits of their realization according to the legislation of Ukraine], Molodyj vchenyj, no. 9 (36), pp. 257-260.

23. Dolinskaya M. S. (2014) Nekotorye aspekty notarial'nogo udostovereniya zaveshchaniy i oformleniya nasledstva na ikh osnovanii v Ukraine [Some aspects 
of the notarization of wills and inheritance registration on the basis of their in Ukraine], Notarial'nyy vestnik, no. 10, pp. 54-62.

24. Naghorna Gh. O. (2009) Realizacija prava na zapovit osoby, jaka perebuvaje pid chas plavannja na sudni [Realization of the right to the will of the person which is during navigation on a vessel]. Forum prava [Forum law] (electronic journal), no. 2, pp. 284-288. Available at: http://nbuv.gov.ua/UJRN/FP index. htm_2009_2_44 (accessed 05 december 2017)).

25. Naghorna A. O. (2010) Posvidchennja zapovitiv nachaljnykamy poshukovykh abo inshykh ekspedycij [Certificate of wills by chiefs of search or other expeditions]. Visnyk Kharkivsjkogho nacionaljnogho universytetu vnutrishnikh sprav, no. 2, pp. 251-255.

26. Sibiljova S. (2012) Umovy dijsnosti zapovitiv za chynnym cyviljnym zakonodavstvom Ukrajiny [Conditions for the validity of the will under the civil legislation law of Ukraine]. Universytetsjki naukovi zapysky, no.3, pp. 202-211.

27. Sibiljova S. (2013) Ponjattja, vydy j naslidky nedijsnykh zapovitiv za chynnym cyviljnym zakonodavstvom Ukrajiny [Conceptiog, types and consequences of invalid wills as to the current civil legislation of Ukraine]. Problemy zakonnosti, vol. 123, pp. 271-281.

28. Chubenko A. Gh., Lesjkiv S. R. (2014) Nikchemnistj zapovitu ta vyznannja zapovitu nedijsnym: cyviljno-pravovi aspekty [Insignificance of will and invalidation of will: civil and legal aspects]. Molodyj vchenyj, no.11(14), pp. 165-168. 